I NOTICE the same phenomenon here, under the sycamore trees, when they are in blossom, which your correspondent $\mathrm{Mr}$. Masheder observed recently under his lime trees, namely, the heads and thoracic segments of severed humble bees lying on the ground, with legs and wings attached, still retaining their vitality in some cases, but without any trace of the abdominal segments, for the sake of whose contents, no doubt, the bees were destroyed. We have no fly-catchers here. I suspect the tomtits, which are abundant in the vicinity of this wholesale apicide, but I have no direct evidence of their guilt. R. V. D.

Beragh, Co. Tyrone, August 15

\section{Migration of the Wagtail}

Apropos of recent letters on this subject in NATURE, permit me to note that on my voyage out to the East Indies in the month of October, 1878, on board the Dutch mail steamer Celebes, two wagtails alighted on the ship when not very far north of the equator (the ship's course being then from Aden to Padang in Sumatra). On observing them I pointed them out to a Dutch friend, who at once recognised them as Krvikstails. They were rather lively, and did not appear to us to be fatigued; after staying with us for some days they took their departure, but in what direction I had not the satisfaction of observing.

Without affirming positively, I believe the species was the Motacilla alba.

Sumatra, June

\section{ITALIAN DEEP-SEA EXPLORATION IN THE} MEDITERRANEAN

A FTER some delay, beyond our control, the warsteamer of the Italian Royal Navy Washington, Capt. G. B. Magnanghi, R.N., left Maddalena on the and inst. on her thallassographic mission. Under the able direction of Capt. Magnaghi, two days were devoted to preliminary dredgings and trawlings in depths from 200 to 1000 metres, principally for testing our apparatus, which works admirably. On the 4 th inst. (yesterday afternoon) we did our first deep-sea dredging in 3000 metres; the dredge came up empty, but I had the pleasure of securing, attached to the hempen tangles, a magnificent specimen of that strange blind Crustacean discovered by the Challenger in the North Atlantic, and named Willemoesia leptodactyla; it is no doubt one of the nost characteristic forms of the deep-sea fauna, and its discovery in the Mediterranean is of very great importance and interest, as all students of thalassography will be fully aware, after what Dr. Carpenter has written on the biological conditions of the deeper parts of that sea. Our specimen of Willemoesia is slightly smaller than the one dredged by the Challenger, and figured in Sir Wyville Thomson's "Atlantic," vol. i. p. 189; but otherwise it differs only in one or two minor details, which may be sexual differences; it was dredged off the west coast of Sardinia.

On account of a slight mishap with our engine we have anchored at Asinara for a couple of days, but shall at once resume our work.

HENRY H. GigLioli

Asinara, Sardinia, August 5

\section{KÖNIG'S WAVE-SIREN}

$\mathrm{E}^{\mathrm{v}}$ VERY musician is painfully familiar with the fact that two notes nearly, but not quite exactly, in unison with one another, produce, when sounded together, a throbbing sound commonly described as the phenomenon of "beats." In the elementary theory of acoustics the cause of beats is shown to be the mutual interference of the two vibrations, one sound interfering with the other and silencing it, when one set of waves is half a vibration behind the other. Just as at certain points on the earth's surface there are no tides when a high tide and a low tide coming from different seas meet, so there is no sound when two sets of sound-waves meet in opposite phases. If the two notes differ just a little in pitch they will alter- nately reinforce and interfere with one another, and produce the throbbing sound of beats, the number of beats (or maxima of sound) per second being the same as the difference in the number of vibrations per second. If one tone makes $m$ vibrations per second and the other $n$ (a slightly smaller number, being a slightly flatter tone) there will be $m-n$ beats per second heard. If this number be not more than 3 or 4 per second the beats can easily be counted. When they get as rapid as 12 or 14 per second they come too fast to be counted, and are very harsh and grating. They are most disagreeable at about 33 per second; and if yet more rapid, are heard as a harsh, disagreeable, rattling sound quite different from a true note. Imperfect octaves and imperfect twelfths likewise cause beats ; in fact there are beats heard for any imperfectly tuned consonance in which the frequency of the higher note is $\mathrm{I}, 2,3,4,5, \ldots$ or any integer number of times that of the lower.

But along with the disagreeable and throbbing phenomenon of beats there arises another phenomenon when two notes not in unison with one another are simultaneously sounded. This is a low booming tone, to which musicians give the name of the "grave harmonic." If two stopped organ-pipes are brought to unison, and then one of them is sharpened by gradually pushing in its stopper, the beats are heard first slow, then fast, then unendurably rapid. But when they reach about twenty or thirty per second the low booming note begins, and rises gradually in pitch as the beats become too rapid to be discriminated. When the higher note has reached a point about half-way between unison and the octave note, the beats are practically imperceptible, and from this point the phenomena recur again, but in inverted order, the grave harmonic falls in pitch down to a low booming tone, while the beats begin again to be distinguishable, grow harsher, then become slower, until when the interval of the octave is reached they also disappear.

A great controversy with respect to these low tones of the grave harmonics has arisen in recent years, and though it smoulders from month to month, occasionally blazes up into vigorous flame. The controverted question is, What are these grave harmonics, and to what are they due? Also, What becomes of the beats when they occur so rapidly that the ear cannot distinguish them? The answer given by Dr. Thomas Young, and by Smith in his "Harmonics" (1749), was that the rapid beats actually passed into the grave harmonic, just as in the generation of any pure tone the separate vibrations (which, when very slow, are beard as separate sounds) blend into one continuous tone whose pitch depends upon their frequency. This view is maintained at the present day with great energy also by the famous acoustician Dr. Rudolph König of Paris, On the other hand, Helmholtz has emphatically maintained that the grave harmonic is not, and cannot be, thus accounted for, and has given very cogent reasons for thinking that it has another explanation; and in this view he is supported by Preyer, Lord Rayleigh, Ellis, Bosanquet, and all the best English physicists. Mere alternations of sound and silence, however rapidly they occur, cannot produce the same effect on the mechanism of the ear as a pure to-and-fro motion of the same periodic frequency. A tuning-fork which vibrates Ioo times per second will give out waves which, falling on the ear, push the drumskin in, and draw it back that number of times per second. But a continuous tone interrupted too times per second by short periods of silence produces quite a different mechanical action on the mechanism of the ear. The writer of this article once tried to ascertain, by the experiment of rotating a vibrating tuning-fork upon its axis, whether the alternations of sound and silence which are observed as it is rotated would blend into a continuous tone; but no kind of blending took place. Another most conclusive proof that the beats and the beat-tones are distinct phenomena is that at a 